\title{
ARTHROSCOPIC TREATMENT OF RUPTURES OF THE ROTATOR CUFF
}

\author{
Radomír Holibka*, Radim Kalina, Miroslav Pach, Katherine Růžičková
}

Clinic of Orthopaedics, Teaching Hospital, Palacký University, I. P. Pavlova 6, 77520 Olomouc, Czech Republic

Received: May 2, 2005; Accepted (with revisions): November 11, 2005

Key words: Muscles of the rotator cuff/Rupture etiology/Arthroscopic treatment

566 patients with shoulder disease were treated at the Clinic of Orthopaedics at the University Hospital Olomouc. Of these, 181 were operated for ruptures of the rotator cuff (RC). They were categorised according to the Gschwend classification, age and gender ${ }^{1}$. Laterality of the operated limb was also evaluated. Patients with ruptures larger than $4 \mathrm{~cm}$ were treated by open operation.

84 shoulders with ruptures classified as Gschwend I, II and IIIa -52 males and 32 females-were treated arthroscopically. The age of the operated patients ranged from 40-60 years. In both genders, the right shoulder was more often affected.

Two operating techniques were used: 1) Transosseal refixation of the RC muscle tendons, using RC MITEK anchor implants, 2) "End to end" sutures, without implants ${ }^{2-4}$.

Operating time was reduced to $30-40 \mathrm{~min}$. The operating results were evaluated according to the UCLA criteriaUniversity of California Shoulder Rating Score 2.45 patients achieved excellent results (53\%), 35 patients had good results ( $42 \%$ ), and 4 patients ( $5 \%$ ) obtained satisfactory results. None of the patients obtained poor results- a score of less than 20 was poor. Patients felt comfortable following the operation and none had any post-operational complications. The author is convinced, along with others, that arthroscopic suturing of RC ruptures classified I-IIIa allows for rupture treatment that in the past had to be treated by open technique ${ }^{2-5}$. The deltoid muscle is not affected by arthroscopy. There is normalisation of the patient's movement, pain, force, and rotational stability is comparable to the healthy limb. Treatment time is reduced to a minimum and the patient may soon return to normal daily life.

\section{INTRODUCTION}

Damage to the RC often causes pain and affects shoulder function. The etiology of RC ruptures ranges from traumatic injury to overuse of the shoulder joint to arthrotic changes in the joint. RC ruptures may be small and without transmural affliction but may extend to massive ruptures leading to destabilisation of the shoulder joint. Ruptures are usually present in patients who are 40 years of age and older, but can also appear in young "overhead" athletes or after acute trauma. The introduction of arthroscopy and arthroscopic surgical techniques have led to significantly improved diagnosis of damage to the $\mathrm{RC}$ and its treatment. RC ruptures belong to the III.grd. stage of the Neer Classification ${ }^{6-7}$. The supraspinatus and infraspinatus muscle tendons are most often damaged. In the later stages the teres minor and subscapularis muscle tendons are affected.

The aim of the study was to: 1 . Perform arthroscopic operation in patients with ruptures classified as I, II, and IIIa according to Gschwend, 2. Operationally treat RC ruptures (using instruments from Johnson and Johnson division DePuy MITEK) using the following techniques: a) Transosseal refixation of rotator cuff tendons using $\mathrm{RC}$ MITEK anchor implants, b) "End to end" suturing, without using implants, 3. Retrospective evaluation using the
UCLA Shoulder Rating Score, 4. Statistically evaluate the results according to age, gender, laterality, size of rupture and frequency of occurrence.

\section{METHODS}

A significant part of the operation was the pre-operational preparation of the patient. This meant not only standard professional preparation but also personal consultation where the operation is explained, as well as the probability of success and possible complications.

We arthroscopically treated rotator cuff ruptures in 75 patients - 45 males and 30 females. Bilateral ruptures were seen in 9 patients. Hence a total of 84 shoulders were arthroscopically operated upon, 62 right and 22 left shoulders. The age of the patients ranged throughout the entire age spectrum, as seen in Tab. 1.

In the first group, 12-30 years of age, we operated 7 shoulders resulting primarily from a traumatic sport injury. The second group comprised 6 , the third 27 , the fourth 33 and the group above 60 years of age included 11 shoulders.

Surgical technique: The optics is introduced by the dorsal "soft spot". In most cases, a superior anterior portal is introduced for the instruments treating intraarticular 
Table 1. Arthroscopically treated shoulders classified according to Gschwend (Gsch) - age distribution.

\begin{tabular}{|c|c|c|c|}
\hline Age & Gsch I & Gsch II & Gsch IIIa \\
\hline $12-30$ & 2 & 5 & 0 \\
\hline $31-40$ & 2 & 4 & 0 \\
\hline $41-50$ & 17 & 9 & 1 \\
\hline $51-60$ & 18 & 12 & 3 \\
\hline above 60 & 1 & 5 & 5 \\
\hline Total & 40 & 35 & 9 \\
\hline
\end{tabular}

pathology. After treating intraarticular pathology, the arthroscope is introduced into the subacromial space using the same skin incision. Then the lateral entry is introduced. A wide "safety zone" is used when introducing ventro-lateral portals to the subacromial space. This means, that every entry must be distanced at least $4 \mathrm{~cm}$ from the acromion edge. In certain large lesions, it is necessary to create an additional working portal. After bursa removal, the defect is identified and evaluated in terms of mobility. The coracoacromial ligament must always remain intact in RC ruptures, even during acromioplasty according to Neer. This had to be performed in some cases.

We use two suturing techniques to anchor the insertion of the rotator cuff tendon:

1. Transosseal refixation of rotator cuff tendons using RC MITEK anchor implants

2. "End to end" suturing, without using implants.

Ad 1) Transosseal refixation of rotator cuff tendons using RC MITEK anchor implants:

The mediolateral mobility of the RC was tested using arthroscopic atraumatic pliers introduced by anterolateral entry.

The detached rotator cuff is pulled towards the osseous attachment area that is prepared by "shaver" at the border between the head and the great tubercle of the humerus. This area corresponds to the area from which the rotator cuff was detached. The soft tissue is removed. Pre-drilling and de-blooding the area prepare attachment for the RC tendon. The cannula is then inserted into the lateral portal.

A “cannulated needle", from the MITEK company, and PDS thread is used for RC suturing. In this way, the torn portion of the RC tendon is attached to the PDS thread, which is pulled out through the lateral portal outside of the joint. The RC MITEK anchor is attached to one end of the PDS thread and mounted onto a special Inserter which is re-introduced to the prepared attachment area by the cannula. Next the "Duncan loop" stitch is seated with the help of the Knot Pusher.

The procedure is repeated for the introduction of a second anchor, if needed. This results in the refixation of the rotator cuff. Utilisation of the cannula is very important for knot advancement, securing soft tissue from catching in the PDS suture knot which could cause the knot to stick and result in insufficient suture tightening.

Ad 2) "End to end" suture without the use of RC MITEK implants.

In transversal or longitudinal acute traumatic ruptures, the suture can only be performed using a MITEK cannulated needle without the use of implants. The sutures are performed "end to end". After exsanguinating to the edges of the $\mathrm{RC}$ rupture using a shaver, both edges of the rupture are sutured together using a cannulated needle. The RC tendon is then hooked to the PDS thread, and using the Knot-Pusher, the Duncan loop is tightened and the suture is complete.

After treating the RC rupture, the skin portals are treated. If full anaesthesia was used, $10 \mathrm{ml}$ of $1 \%$ mesocaine are introduced into the shoulder joint. A Dessault bandage is attached according to the Zahradníček modification. Fixation is maintained for 4 weeks. After 14 days the patients exercise movements in the wrist and elbow. After 4 weeks the fixation is removed and a 21-day controlled passive exercise regime begins in the shoulder joint. After 8 weeks, active exercise is allowed. Isotonic exercise is permitted after 12 weeks post-operation with focus on strengthening the muscles of the rotator cuff and the stabilizers of the scapula.

\section{RESULTS}

Operation success, for comparison with foreign authors, was evaluated according to the modified UCLA Score- University of California Shoulder Scoring System ${ }^{4}$.

We found operational results to be surprisingly good. Of the 84 performed arthroscopic operations (100\%), refixation of the rotator cuff by RC MITEK anchors was performed on 43 shoulders where 24 shoulders achieved excellent results (56\%), 16 (37\%) had good results, and 3 shoulders ( $7 \%$ ) achieved satisfactory results.

Of the "end to end" suturing technique, 22 (54\%) achieved excellent operational results, 18 (44\%) had good results, and only 1 ( $2 \%)$ shoulder operation was evaluated as satisfactory.

Total results of shoulder operations:

46 operations excellent $(53 \%)$

34 operations good

4 operations satisfactory $(5 \%)$

All patients considered their operation successful, were rid of pain, muscle strength and function improved. The average score was 36 points. None of the patients obtained a score lower than 25 points.

\section{DISCUSSION}

The first to describe the surgical suturing of the supraspinatus muscle was Codman, in 1911( ref. $^{8}$ ). The operation was done by open technique through the deltoid muscle. Open operations were successfully performed for 
Table 2. Postoperative results in 84 shoulders.

\begin{tabular}{|c|c|c|c|c|c|c|c|c|}
\hline & \multicolumn{2}{|c|}{ Excellent } & \multicolumn{2}{c|}{ Good } & \multicolumn{2}{c|}{ Satisfactory } & \multicolumn{2}{c|}{ Total } \\
\hline E - E & 22 & $54 \%$ & 18 & $44 \%$ & 1 & $2 \%$ & 41 & $49 \%$ \\
\hline MITEK & 24 & $56 \%$ & 16 & $37 \%$ & 3 & $7 \%$ & 43 & $51 \%$ \\
\hline Total & 46 & $55 \%$ & 34 & $40 \%$ & 4 & $5 \%$ & 84 & $100 \%$ \\
\hline
\end{tabular}

E - E "End to end" suturing technique

MITEK Technique using MITEK anchor implants

Table 3. Postoperative results according to gender.

\begin{tabular}{|c|c|c|c|c|c|c|c|c|c|c|c|c|c|c|}
\hline \multirow{3}{*}{ gender } & \multicolumn{4}{|c|}{ Excellent } & \multicolumn{4}{|c|}{ Good } & \multicolumn{4}{|c|}{ atisfactory } & \multirow{2}{*}{\multicolumn{2}{|c|}{$\begin{array}{c}\text { Number of } \\
\text { Operated } \\
\text { Shoulders }\end{array}$}} \\
\hline & \multicolumn{2}{|c|}{ Males } & \multicolumn{2}{|c|}{ Females } & \multicolumn{2}{|c|}{ Males } & \multicolumn{2}{|c|}{ Females } & \multicolumn{2}{|c|}{ Males } & \multicolumn{2}{|c|}{ Females } & & \\
\hline & $\mathrm{R}$ & $\%$ & $\mathrm{R}$ & $\%$ & $\mathrm{R}$ & $\%$ & $\mathrm{R}$ & $\%$ & $\mathrm{R}$ & $\%$ & $\mathrm{R}$ & $\%$ & $\mathrm{R}$ & $\%$ \\
\hline$E-E$ & 9 & 41 & 13 & 68 & 12 & 54 & 6 & 32 & 0 & 0 & 1 & 5 & 41 & 49 \\
\hline MITEK & 18 & 60 & 6 & 46 & 10 & 33 & 6 & 46 & 2 & 7 & 1 & 8 & 43 & 51 \\
\hline Total & 27 & 52 & 19 & 59 & 22 & 42 & 12 & 38 & 3 & 6 & 1 & 3 & 84 & 100 \\
\hline
\end{tabular}

E - E "End to end" suturing technique

MITEK Technique using MITEK anchor implants

a long time and have successfully evolved to present times, due to improved instruments and operating techniques. The constant development of arthroscopic instruments leads orthopaedic surgeons to utilise new operational mini-invasive methods.

Johnson was the first to perform an arthroscopic operation of the shoulder joint ${ }^{9}$. He used metal staples to fixate the tendon of the rotator cuff to the great tubercle of the humerus. This method of refixation, however, required the staples to be removed after certain time. This resulted in a two-phase operation. Eventually new arthroscopic techniques evolved, normally used in parallel, according to the extent of the $\mathrm{RC}$ rupture.

The introduction of RC MITEK anchors brought forth a fairly exclusive procedure for refixation of RC ruptures. E. Wolfe first used the anchors in 1989(ref. $\left.{ }^{4}\right)$, and later, along with his colleagues, published excellent results on a set of 104 patients. Only 4 of his patients obtained poor results after evaluation according to the UCLA Score. However, no loss of motion was observed as a result of the operation. Wolfe's patients obtained an average score of 32 points. The average score of our set of 84 operated patients was 36 and none of our patients, according to the UCLA Score, obtained an unsatisfactory result. Due to this modern surgical arthroscopic technique, it is possible to safely perform RC suturing or refixation ${ }^{2,4,9-14}$. We are convinced, along with other foreign authors, that arthroscopic suturing of $\mathrm{RC}$ ruptures allows for a higher quality treatment of RC ruptures. The open technique, however, is still a standard method, which if performed properly brings about good results ${ }^{15-17}$. There is however the risk of damage to the axillary nerve followed by muscle hypotrophy. From our first experience, it is apparent that with proper indication, experience of the operator, correct technical procedure and post-operative regime, the performed RC rupture refixation reduces the treatment time to a minimum and allows for a rapid return to normal daily life.

\section{REFERENCES}

1. Gschwend N, Bloch HR, Bischov A. (1991) Langzeitergebnisse der operierte Rotatorenmanschettenruptur. Ortopädie 20, 255-261

2. Wolf E. (1998) In: Current techniques in arthroscopy. Ed. 3. New York. Time 1998.

3. Wolf E, Pennington W, T, Agrawal V. (2004) Arthroscopic rotator cuff repair. Arthroscopy 20, 2-12.

4. Yamaguchi K, Ball C, M, Galatz L, M. (2001) Arthroscopic rotator cuff repair: transition from mini - open to all arthroscopic. Clin Orthop 390, 83-94.

5. Neer C, S, 11, Flatow E, L, Lech O. (1988) Tears of the rotator cuff: Long term results of anterior acromioplasty and repair. Orthop Trans 12, 735-737.

6. Neer C, S, 11. (1972) Anterior acromioplasty for the chronic impingement syndrome in the shoulder: A preliminary report. Journal of Bone and Joint Surgery 54, 41-50. 
7. Codman E, A. (1911) Complete Rupture of the Supraspinatus Tendon - Operative Treatment with Report of Two Successful Cases. (1911) Boston Med Surg J 164, 708-710.

8. Holibka R, Ditmar D.(2001) Arthroscopic Treatment of the Rotator cuff - two years results. Artroskopické dny s mezinárodní účastí ČSOT, Poděbrady, ISBN 80-7262-122-X, 41.

9. Holibka R, Ditmar R, Holibková A, Laichman S, Růžičková K.(2003) Isolated ruptures of the supraspinatus muscle. Biomed Papers 147, 227-232.

10. Holibka R, Holibková A, Laichman S, Růžičková K. (2003) Some peculiarties of the rotator cuff muscles. Biomed Papers 142, $227-$ 232.

11. Holibka R, Laichman S, Holibková A, Růžičková K. (2004) The signifikance of the supraspinatus muscle in surgery of the shoulder joint. Abstracts to the $42^{\text {nd }}$ Congress of the Slovak Anatomical Society with International Participation. Edičné stredisko UPJŠ, Košice 2004, s. 52. ISBN 80-7097-554-7.

12. Holibka R. (2004) Arthroskopická léčba ruptur manžety rotátorů. Dizertační práce, Ortopedická klinika FN v Olomouci.

13. Podškubka A, Staša M, Dvořák V, Vaculík J. (2000) Artroskopická subakromiální dekomprese. Acta Chir Ortop Traum Čech 67, 175180.

14. Schroder J, van Dijk CN, Wielinga A, Kerkhoffs GM, Marti RK. (2001) Open versus arthroscopic treatment of chronic rotator cuff impingement. Archive of orthopedic and trauma surgery 121, 241-244.

15. Chomiak J. (1997) Nové zkušenosti s rekonstrukčními operacemi u ruptur rotátorové manžety. Acta Chir Ortop Traum Čech 64, $176-182$. 